\title{
Lettuce Response to Composted Broiler Litter as a Potting Substrate Component
}

\author{
R.P. Flynn', C.W. Wood ${ }^{2}$, and E.A. Guertal ${ }^{3}$ \\ Department of Agronomy and Soils, 202 Funchess Hall, Auburn University, AL 36849-5412
}

\begin{abstract}
Additional index words. Lactuca sativaheavy metals, toxicity, waste management, plant nutritionGallus gallus
Abstract. A glasshouse study was conducted to evaluate the suitability of composted broiler chicken (Gallus gallus) litter as a potting substrate using lettuce (Lactuca sativa L.). Broiler litters containing wood shavings or peanut bulls as bedding materials were composted with either shredded pine bark or peanut hulls. Composted materials were then combined with a commercially available potting substrate. Greatest fresh weight yield was obtained when peanut bull compost was mixed with commercial potting substrate at a ratio of 3:1. Fresh weight was less with pine bark compost than with peanut hull compost. However, there were no differences in lettuce dry weight among composts except for pine bark composted with wood-shaving broiler litter. The pH of this material was below the lettuce tolerance level for mixes at or above $50 \%$ compost. There was no evidence of lettuce physiological disorders resulting from excessive nutrient concentration. Most elements analyzed (N, P, K, Ca, Mg, Fe, Mn, Cu, Zn, and Al) were within or slightly above sufficiency ranges for Bostontype leaf lettuce. It appears that composting broiler litter for use as a potting substrate or component would be one suitable alternative to land application in the southern United States. We recommend, however, that the pH of substrates be adjusted to suit desired crop requirements.
\end{abstract}

Nine southern states (Alabama, Arkansas, Florida, Georgia, Mississippi, North Carolina, South Carolina, Tennessee, and Texas) produced nearly $80 \%$ (five billion) of the nation's broiler chickens in 1992 (USDA-NASS, 1993a). These birds contributed nearly 8 million $\mathrm{Mg}$ of broiler litter (a mixture of chicken excreta, bedding material, water, and wasted feed) to the waste stream. Typically, litter has been applied to pasture and cropland for disposal. However, row-crop acreage over the last 10 years has declined in some parts of the southern United States (AASS, 1993), and suitable farmland continues to be urbanized. Furthermore, economics of transporting litter (Bosch and Napit, 1992) long distances from the production areas will make land application more difficult. Repeated application to small land areas is of concern owing to potential environmental and agronomic problems, including degradation of surface and groundwater quality (Hall, 1993; Kingery et al., 1994; Wood, 1992) and nutrient and heavy metal accumulations in soils and plants (Kingery et al., 1993; Wilkinson, et al., 1971; Wood, 1992). The National Research Council (1993) has stated that reducing excessive nutrient loading to cropland will be difficult unless alternative means of processing, transporting, or marketing manure or products derived from manures are developed.

Fresh broiler litter is a valuable resource as a soil amendment and a fertilizer (Stevenson et al., 1990; Wood, 1992). However, additional processing via composting can add to its value. Biodegradation that occurs during composting makes the material more desirable than fresh litter for improving soil physical conditions as described by Hileman (1967). Initial decomposition has already occurred, and the compost provides slow-release nutrients for plant uptake. Several concerns arise when composted material is used as a potting substrate component, including compost maturity and accumulation of metals in edible tissue. An immature compost

Received for publication 23 Jan. 1995. Accepted for publication 17 July 1995 Mention of a trademark or vendor does not imply its approval to the exclusion of others that may be suitable. The cost of publishing this paper was defrayed in part by the payment of page charges. Under postal regulations, this paper therefore must be hereby marked advertisement solely to indicate this fact.

'Graduate research assistant.

${ }^{2}$ Alumni associate professor.

${ }^{3}$ Assistant professor. competes with roots for Q2and N (Golueke, 1977) and can shrink due to continued decomposition (Raviv et al., 1987). Metal accumulations are typically limited to composts made from municipal sources with relatively high concentrations of heavy metals such as $\mathrm{Pb}, \mathrm{Cd}, \mathrm{Co}, \mathrm{Cr}$, and other potentially toxic metals (Chaney and Giordano, 1977). Composts made from broiler litter typically do not contain excessive quantities of phytotoxic heavy metals. However, Chen et al. (1988), Dowdy and Larson (1975), McKenna et al. (1991), and Walker and Welch (1987) have observed high concentrations of $\mathrm{Cu}, \mathrm{Zn}, \mathrm{Fe}$, and $\mathrm{Al}$ that may cause physiologic problems for plant growth (Chaney, 1983). Other elements of concern from a plant nutrition standpoint include $\mathrm{N}, \mathrm{P}, \mathrm{Ca}$, and $\mathrm{Mg}$. Lettuce has been shown to be a nutrient accumulator (Dowdy and Larson, 1975) and is a good indicator crop to ascertain substrate suitability.

Potted-plant production in nine leading broiler producing states in the southern United States has been steadily increasing, resulting in nearly $\$ 1.2$ billion in wholesale in 1992 (USDA-NASS, 1993b). Suitable substitutes for common components of soilless substrate (peatmoss, tree bark, sand, vermiculite, and perlite) are needed as costs for potting substrates rise and availability is reduced (Pokorny, 1982; Wang and Pokorny, 1989). Pine bark and peanut hulls have been shown to be effective soil amendments and can possibly be used as a potting substrate or component (Bilderback et al., 1982). Peanut hulls have shown some phytotoxic effects (Robinson and Burdick, 1978). However, high temperatures such as those incurred during composting neutralize some phytotoxic effects (Hoitink, 1980; Robinson and Burdick, 1978). Pine bark is also a common substrate in the southern United States as a byproduct of the lumber industry (Pokorny, 1982). Pine bark has an added benefit of pathogen suppression (Hoitink, 1980; Pokorny, 1982) and has been shown to compost well with broiler litter (Flynn and Wood, 1992). Composted broiler litter may be a suitable potting substrate or an extender for many general-use, allpurpose potting substrates. However, effects of using co-composted peanut hulls or pine bark and broiler litter as a potting substrate have been largely unexplored. The objective of this study was to evaluate the suitability of composted broiler litter as a potting substrate or component using lettuce as an indicator crop for yield and nutrient uptake variables. 


\section{Materials and Methods}

Composted materials were as follows: 1) broiler litter containing wood shavings as bedding material composted with peanut hulls (peanut hull compost I); 2) broiler litter-containing peanut hulls as bedding material composted with additional peanut hulls (peanut hull compost II); 3) broiler litter containing wood shavings as bedding material composted with shredded pine bark (pine bark compost III); and 4) broiler litter containing peanut hulls as bedding material composted with shredded pine bark (pine bark compost IV). All materials were composted for 90 days with frequent aeration, then stored in covered and shaded containers at ambient temperature for 2 years (Flynn and Wood, 1992) before use in this study. Nutrient changes in the compost during storage were considered negligible due to the recalcitrant nature of composted material and the protected environment in which the composts were kept. Selected characteristics of the composted materials are given in Table 1. Each compost was sieved through a 0.5$\mathrm{cm}$ screen and then mixed with potting substrate (Promix; Premier Brands, Red Hill, Pa.) at a volume ratio (compost : Promix) of 0:1 (0\% compost), 1:3 (25\% compost), 1:1 (50\% compost), 3:1 (75\% compost), 1:0 (100\% compost). Promix is a general-purpose growing substrate containing $75 \%$ to $85 \%$ sphagnum peat by volume, perlite, vermiculite, dolomitic and calcitic limestone, and a wetting agent.

Plastic pots, $19 \mathrm{~cm}$ in diameter, contained the potting substrates in a controlled-environment glasshouse. Each pot held $5.0 \times 10$ $\mathrm{m}^{3}$ of material. Drainage holes in the pots were plugged with duct tape to limit loss of substrate through the holes but allow drainage. Each pot was leached with tap water (three pot volumes) and allowed to drain thoroughly before planting. Each compost mixture was considered a treatment for a total of 20 treatments, which were arranged in a randomized complete block with six replications. 'Black Seeded Simpson' leaf lettuce seeds (41-day maturity) were pregerminated for $16 \mathrm{~h}$ in aerated $26.7 \mathrm{C}$ water as recommended by Lorenz and Maynard (1988), then planted $6 \mathrm{~mm}$ deep in each pot on 21 Jan. 1994. Pots were covered with clear plastic and misted twice daily for the first 5 days during daylight hours to keep substrate surfaces moist and promote germination. Germination was complete 7 days after planting (DAP). Average daily glasshouse temperature was $20 \mathrm{C}$ with extremes of 10 and 29C. Relative humidity ranged from $40 \%$ to $98 \%$.

All treatments were fertilized equally to emphasize the use of composted broiler litter as a potting substrate. Any potential fertility problems associated with use of composted broiler litter would be expressed in the growth response of the lettuce tissue. Nutrient totals supplied to each pot were calculated from fertilizer volume applied to actively growing lettuce (Table 2). Each pot was fertilized according to lettuce age and potting substrate moisture with irrigations containing an average $0.46 \mathrm{~g} \mathrm{~N} /$ liter, $0.34 \mathrm{~g}$ P/liter and $0.39 \mathrm{~g} \mathrm{~K} /$ liter. Plants were thinned to five plants per pot 20 DAP and to two plants per pot 35 DAP. After the final thinning, fertilizer was applied daily with a modified Hoagland and Arnon (1950) solution (Table 2) to avoid any micronutrient deficiencies. Pots were irrigated with tap water every 5 to 7 days to avoid a salt buildup. Insect pests were controlled as needed with best available management practices by the glasshouse supervisor. Plants were harvested 56 DAP.

Lettuce was cut at the substrate surface, immediately weighed for fresh weight, then dried at $60 \mathrm{C}$ for $52 \mathrm{~h}$. Plants were reweighed for dry weight and ground to pass through a $0.5-\mathrm{mm}$ sieve. Lettuce $\mathrm{N}$ content was determined with an analyzer (model CHN-600; LECO Corporation, St. Joseph, Mich.). Total P, K, Ca, Mg, Mn, $\mathrm{Cu}, \mathrm{Fe}$, and $\mathrm{Zn}$ were analyzed by inductively coupled argon plasma (ICAP) spectroscopy (model 9000; ThermoJarrell Ash, Franklin, Mass.) after 0.5-g lettuce samples were ashed in a muffle furnace at $550 \mathrm{C}$ for $8 \mathrm{~h}$ followed by dissolution of remaining ash in $0 . \mathrm{N}$

$\mathrm{HNO}_{3}$. The solution was heated to dryness and extracted in hot 0.1 $\mathbf{N ~ H C l}$. Compost substrate $\mathrm{pH}$ and EC were determined at lettuce harvest with a $\mathrm{pH}$ meter and glass electrode and a conductivity meter; five subsamples taken with a 3-cm-diameter soil sampling tube from each pot were cornposited and then combined with distilled water at a 1 moist potting substrate : 2 water volume ratio.

Data analyses on yield components, nutrient concentration, and nutrient uptake included SAS (1988) for regression and general linear models (Freund and Littell, 1991). Regression procedures with stepwise addition of significant independent variables were used. The proposed adequate model for the study was as follows:

$E\left(Y_{x}\right)=\left(\beta_{o}+\Delta_{1} \beta_{o} U_{1}\right)+\left(\beta_{1}+\Delta_{1} \beta_{1} U_{1}\right) x_{1}+\left(\beta_{2}+\Delta_{1} \beta_{2} U_{1}\right) x_{1}^{2}$

Table 1. Total element composition of composted materials and Promix.

\begin{tabular}{|c|c|c|c|c|c|c|}
\hline \multirow[b]{2}{*}{ Element $^{y}$} & & \multicolumn{2}{|c|}{ Peanut hull } & \multicolumn{2}{|c|}{ Pine bark } & \multirow[b]{2}{*}{ Promix } \\
\hline & & Compost I & Compost II & Compost III & Compost IV & \\
\hline Total N $\left(\mathrm{g} \cdot \mathrm{kg}^{-1}\right)$ & & 27.1 & 23.1 & 16.4 & 13.9 & 4.10 \\
\hline $\mathrm{NO}_{3}-\mathrm{N}\left(\mathrm{mg} \cdot \mathrm{kg}^{-1}\right)$ & & 2061 & 1513 & 882 & 862 & 52 \\
\hline $\mathrm{NH}_{4}-\mathrm{N}\left(\mathrm{mg} \cdot \mathrm{kg}^{-1}\right)$ & 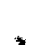 & 40 & 13 & 285 & 923 & --- \\
\hline$P\left(g \cdot \mathrm{kg}^{-1}\right)$ & $*$ & 9.2 & 8.8 & 5.9 & 8.6 & 0.73 \\
\hline $\mathrm{K}\left(\mathrm{g} \cdot \mathrm{kg}^{-1}\right)$ & & 20.7 & 20.2 & 8.8 & 12.1 & 2.1 \\
\hline $\mathrm{Ca}\left(\mathrm{g} \cdot \mathrm{kg}^{-1}\right)$ & & 12.4 & 12.2 & 10.8 & 12.4 & 29.8 \\
\hline $\mathrm{Mg}\left(\mathrm{g} \cdot \mathrm{kg}^{-1}\right)$ & & 3.7 & 3.3 & 4.9 & 2.8 & 2.9 \\
\hline $\mathrm{Fe}\left(\mathrm{mg} \cdot \mathrm{kg}^{-1}\right)$ & & 2113 & 1411 & 1604 & 1632 & 177 \\
\hline $\operatorname{Mn}\left(\mathrm{mg} \cdot \mathrm{kg}^{-1}\right)$ & & 244 & 241 & 227 & 282 & 166 \\
\hline $\mathrm{Zn}\left(\mathrm{mg} \cdot \mathrm{kg}^{-1}\right)$ & & 218 & 188 & 151 & 215 & 77 \\
\hline $\mathrm{Cu}\left(\mathrm{mg} \cdot \mathrm{kg}^{-1}\right)$ & & 153 & 213 & 177 & 242 & 54 \\
\hline $\mathrm{Al}\left(\mathrm{mg} \cdot \mathrm{kg}^{-1}\right)$ & & 1803 & 1649 & 2729 & 2501 & -- \\
\hline $\operatorname{Ash}\left(\mathrm{g} \cdot \mathrm{kg}^{-1}\right)$ & & 150 & 260 & 180 & 380 & 381 \\
\hline $\mathrm{C}: \mathrm{N}$ & & 25 & 22 & 28 & 22 & 68 \\
\hline $\mathrm{EC}\left(\mathrm{S} \cdot \mathrm{m}^{-1}\right)$ & & 4.77 & 6.02 & 5.20 & 6.86 & 0.12 \\
\hline $\mathrm{pH}$ & & 6.0 & 6.0 & 6.0 & 5.3 & 5.48 \\
\hline
\end{tabular}

${ }^{2}$ Refer to methods for material description. EC = electrical conductivity.

Average of two samples. 
Table 2. Modified Hoagland and Arnon (1950) stock nutrient solutions and full-strength watering solution used to fertilize lettuce.

\begin{tabular}{lcc}
\hline \hline $\begin{array}{l}\text { Solution } \\
\text { composition }^{\mathrm{z}} \\
\left(\mu \mathrm{mol} \cdot \text { liter }^{-1}\right)\end{array}$ & $\begin{array}{c}\text { Nutrients } \\
\text { applied } \\
\mathrm{mg} / \mathrm{pot}\end{array}$ \\
\hline $\mathrm{N}$ & 12160 & 8000 \\
$\mathrm{P}$ & 2331 & 5000 \\
$\mathrm{~K}$ & 4475 & 7000 \\
$\mathrm{Ca}$ & 3955 & 1700 \\
$\mathrm{Mg}$ & 2122 & 600 \\
$\mathrm{~S}$ & 2133 & 800 \\
$\mathrm{Fe}$ & 41.18 & 1300 \\
$\mathrm{Cl}$ & 18.62 & --- \\
$\mathrm{B}$ & 9.25 & 1.0 \\
$\mathrm{Mn}$ & 3.64 & 2.2 \\
$\mathrm{Zn}$ & 0.76 & 0.5 \\
$\mathrm{Mo}$ & 0.17 & 0.2 \\
$\mathrm{Cu}$ & 0.16 & 0.1 \\
\hline
\end{tabular}

${ }^{3}$ Final solution was adjusted to $\mathrm{pH} 6.0$ with $0.1 \mathrm{~N} \mathrm{NaOH}$ or $1 \mathrm{~N} \mathrm{HCl}$.

where,

$E\left(Y_{x}\right)=$ the expected value of $Y$ due to the influence of independent factors

$\mathrm{X}_{1}=$ percentage of compost mixed with commercially available potting substrate

$\beta_{\mathrm{o}}=$ the $\mathrm{Y}$ axis intercept

$\Delta_{1} \beta_{\mathrm{o}}=$ correction to the intercept due to use of compost

$\beta_{1}=$ slope coefficient of the linear percentage compost term

$\Delta_{1} \beta_{1}=$ correction to the linear slope coefficient due to use of compost

$\beta_{2}=$ slope coefficient of the quadratic percentage compost term

$\Delta_{\lambda} \beta_{2}=$ correction to the quadratic slope coefficient due to use of compost

$\mathrm{U}_{1}=1$, if commercial potting substrate alone or in combination with compost caused a deviation away from the combined response to percentage compost, otherwise $U=0$.

The probability level used for insertion of an independent variable in the statistical model was $\mathrm{a}=0.10$.

The statistical approach allowed for the separation of dependent variable response due to composts in combination with or without Promix, which is an advantage over a standard analysis of variance approach (Wood and Westfall, 1989). The separation of dependent variables was important because it delineated the difference in yield and nutrient uptake response to compost percentages among compost sources in combination with a commercially available potting substrate. The regression procedure also allowed generation of plotting equations so that response differences could be visualized. The approach also allowed for inclusion of higherorder (quadratic) terms in the statistical models for a check of deviation from linearity. One coefficient of determination $R^{2}$, for all plotting equations, measures the contribution of the linear function of the independent variables to the variation in yield and nutrient uptake. All plotting equations were significant $i f R^{2}$ was significantly different from zero using $\mathrm{F}$ tests at $\mathrm{a}=0.10$.

\section{Results and Discussion}

Generally, lettuce yields were greater for composts mixed with Promix than for Promix alone (Fig. 1). No statistical difference existed between fresh weights from the two peanut hull composts (Fig. 1), and yields were comparable to those obtained by Dowdy and Larson (1975). Lettuce fresh weight was greatest when peanut hull compost was mixed with Promix at a ratio of 3:1 (compost : Promix) producing $220 \mathrm{~g} / \mathrm{plant}$. Fresh weights from pine bark compost were less than yields from peanut hull compost. However, yields with $100 \%$ pine bark compost IV and $100 \%$ peanut hull composts were similar. Lettuce fresh weight yield from pine bark compost III was lowest of the four composts maximizing at the 3:1 mixture with $160 \mathrm{~g} /$ plant.

Lettuce dry weight was also significantly affected by percentage compost in a curvilinear manner, with greatest dry weight (19 g/plant) occurring at the 3:1 and 1:0 mixture of both peanut hull composts and pine bark compost IV (Fig. 1). Pine bark compost III also followed a quadratic relationship; however, dry weight maximized at the $1: 1$ mixture $(16 \mathrm{~g} /$ plant $)$.

We suspect that fresh weights were reduced with pure composts

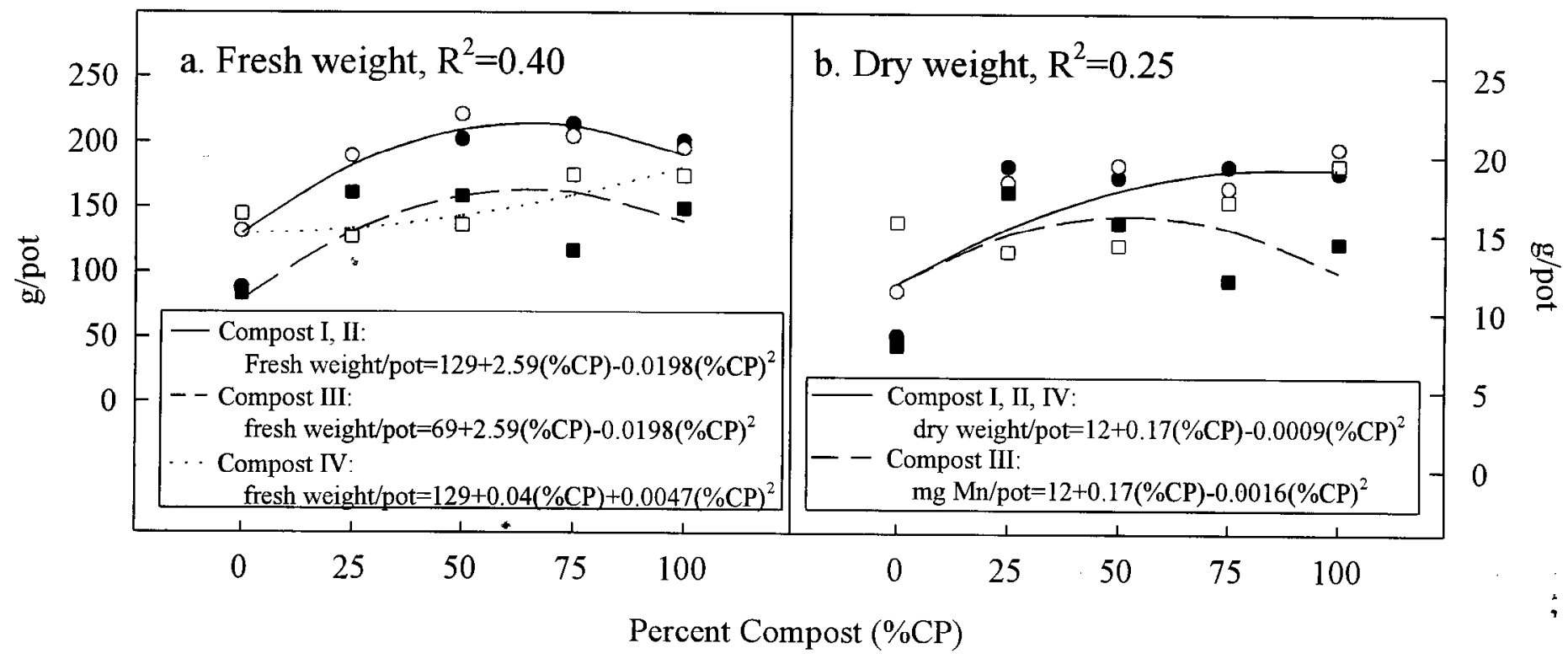

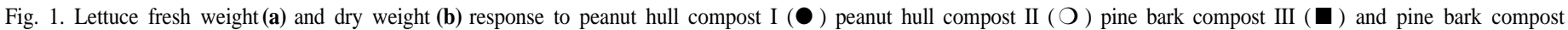

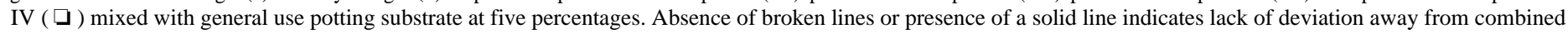
response to percentage compost. 
Table 3. Nutrient sufficiency ranges for lettuce and nutrient concentration range found within lettuce grown in composted broiler litter potting substrate.

\begin{tabular}{|c|c|c|c|c|c|}
\hline \multirow[b]{2}{*}{ Element } & \multirow[b]{2}{*}{ Sufficiency $^{z}$} & \multicolumn{2}{|c|}{ Peanut hull } & \multicolumn{2}{|c|}{ Pine bark } \\
\hline & & Compost I & Compost II & Compost III & Compost IV \\
\hline \multicolumn{6}{|c|}{$\mathrm{g} \cdot \mathrm{kg}^{-1}$} \\
\hline $\mathrm{N}$ & $47-55$ & $46-52$ & $39-50$ & $56-64$ & $48-56$ \\
\hline $\mathrm{P}$ & $5-10$ & $10-14$ & $9-12$ & $11-13$ & $11-12$ \\
\hline $\mathrm{K}$ & $75-90$ & $57-109$ & $45-79$ & $86-125$ & $80-112$ \\
\hline $\mathrm{Ca}$ & $20-30$ & $12.4-17.4$ & $11.8-15.5$ & $11-14$ & $9-12$ \\
\hline \multicolumn{6}{|c|}{$m g \cdot k g^{-1}$} \\
\hline $\mathrm{Cu}$ & $8-25$ & $11-28$ & $8-26$ & $9-59$ & $11-88$ \\
\hline $\mathrm{Fe}$ & $50-100$ & $58-136$ & $85-151$ & $85-275$ & $61-156$ \\
\hline Mn & $15-250$ & $203-273$ & $263-324$ & $276-482$ & $226-316$ \\
\hline $\mathrm{Zn}$ & $25-250$ & $78-100$ & $81-95$ & $108-135$ & $77-114$ \\
\hline $\mathrm{Al}$ & --- & $51 \cdot 114$ & $39-96$ & $63-308$ & $71-125$ \\
\hline
\end{tabular}

$\overline{{ }^{2}}$ Oldest leaf, eight-leaf stage, Boston type leaf lettuce (Jones et al., 1991).

due to lower water-holding capacity (not measured) and an ob- tion is 6.0 to 6.8 (Lorenz and Maynard, 1988). The pH of all served tendency for plants to begin wilting before treatments compost : Promix combinations were below the recommended having lower compost : Promix ratios. Fresh and dry weights from minimum, averaging 5.7 for both peanut hull composts and pine lettuce grown in pine bark compost IIImay have been affected by bark compost IV. Despite a pH slightly lower than optimum for $\mathrm{pH}$ of the material. The recommended $\mathrm{pH}$ range for lettuce produc- peanut hull composts and pine bark compostIV, there appeared to

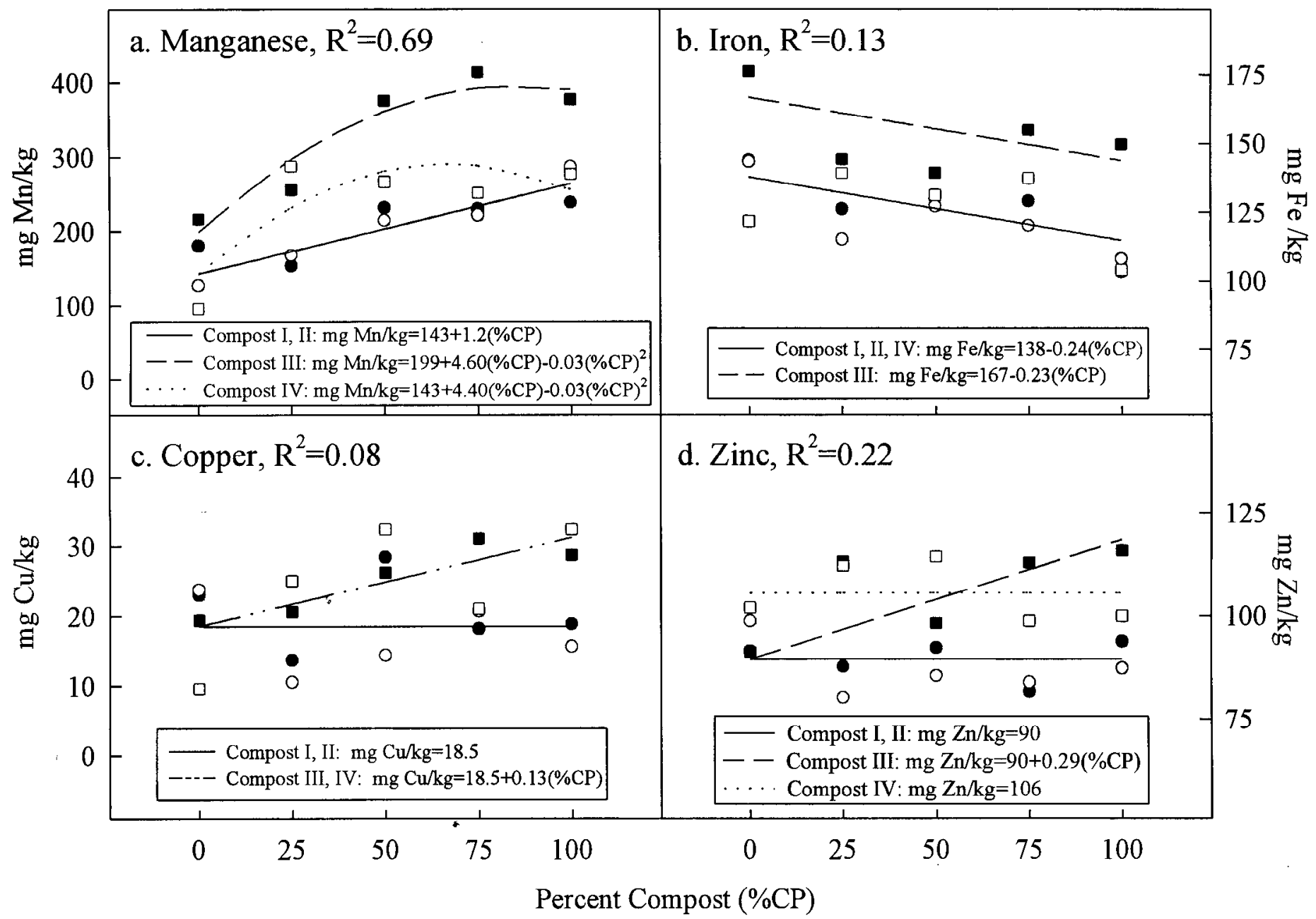

Fig. 2. Lettuce (a) $\mathrm{Mn},(\mathbf{b}) \mathrm{Fe},(\mathbf{c}) \mathrm{Cu}$, and (d) $\mathrm{Zn}$ concentrations in aerial lettuce tissue as affected by peanut hull compost I P ) peanut hull compost II ( $\bigcirc$ ) pine bark compost III ( $)$ and pine bark compost IV ( $\square$ ) and percentage of compost in the potting substrate. Absence of broken lines or presence of a solid line indicates lack of deviation away from combined response to percentage compost. 


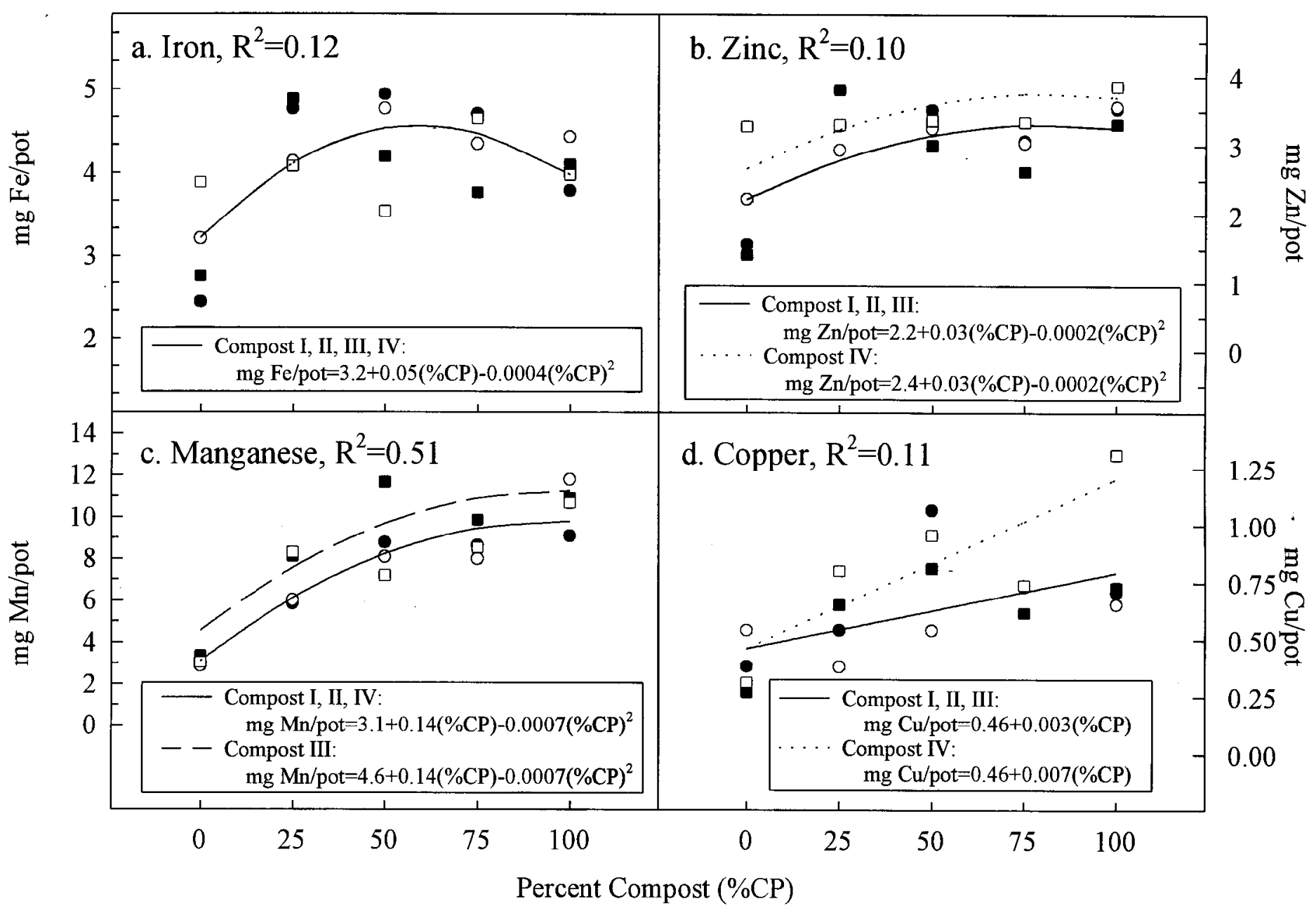

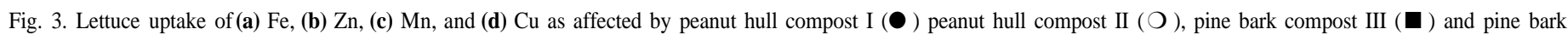

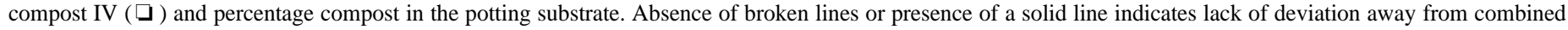
response to percentage compost.

be no adverse effect on yield. However, $\mathrm{pH}$ of pine bark compost necessary, treated with limestone or another acid-neutralizing III declined linearly from 5.7 to 5.0 as percentage of compost compound if $\mathrm{pH}$-sensitive plants are to be grown. The acidic increased to $100 \%$. Lettuce fresh and dry weights from pots with potting substrate most likely had the greatest effect on nutrient pine bark compost III decreased in mixtures containing more than concentration of lettuce grown in pine bark compost III. Manga$50 \%$ compost (Fig. 1), which corresponded to a $\mathrm{pH}<5.5$.

Nutrient analysis of lettuce tissue from compost : Promix mixtures was used to screen composted materials for any physiologically damaging effects resulting from $\mathrm{Cu}, \mathrm{Zn}$, or $\mathrm{Mn}$. Nutrients were supplied from both composted materials and nutrient solutions applied with irrigations. Mixing Promix with composts diluted the concentration of nutrients originating in composts. Nutrient concentrations of each potting substrate were not measured since all treatments were irrigated identically with nonlimiting amounts of fertilizer. Despite confounding effects of nutrients in composts, potential toxicities or excessive accumulations of minerals as a result of using composted broiler litter as potting substrate or substrate component can still be evaluated. nese will compete with Fe for plant uptake (Mengel and Kirkby, 1982), which may explain the decreasing trend in Fe concentration from lettuce tissue as $\mathrm{Mn}$ concentration increased (Fig. 2b). Manganese concentrations, however, were not excessively high (Jones et al., 1991) (Table 3) and did not appear to present a physiologic problem to lettuce. Dowdy and Larson (1975) reported a large increase in $\mathrm{Cu}(1.6$ to $11.9 \mathrm{mg} \cdot \mathrm{kg})$ in lettuce leaves from the use of municipal sludge. Tissue concentration of $\mathrm{Cu}$ from our experiment indicated no change with increasing percentages of compost except for pine bark compost III and IV (Fig. 2c). There was a linear increase in $\mathrm{Cu}$ concentration from pine bark compost III and IV, reaching a predicted maximum of $32 \mathrm{mg} \cdot \mathrm{kg}$ at $100 \%$ compost. Some caution must be exercised here since only $8 \%$ of Most micronutrients were within or slightly above sufficiency the variation in Cu concentration in lettuce was related to percentranges for lettuce tissue (Table 3) (Jones et al., 1991). However, age of compost mixed with Promix. The apparent increase in Cu lettuce from pine bark compost III exhibited an accumulation of may be related to $\mathrm{pH}$ of the substrates, but the concentration was; Mn (Fig. 2a), most likely due to effects of pH (Mengel and Kirkby, not deemed excessive. Zinc concentration of lettuce tissue was 1982). Pine bark compost IV also exhibited an increase in Mn within sufficiency ranges for all composted materials (Table 3), concentration compared to peanut hull composts, indicating that and pine bark compost IV apparently contributed more Zn to composts made from pine bark should be tested for $\mathrm{pH}$ and, if lettuce as evidenced by a greater overall mean of $106 \mathrm{mg} \mathrm{Zn} / \mathrm{kg}$ vs. 


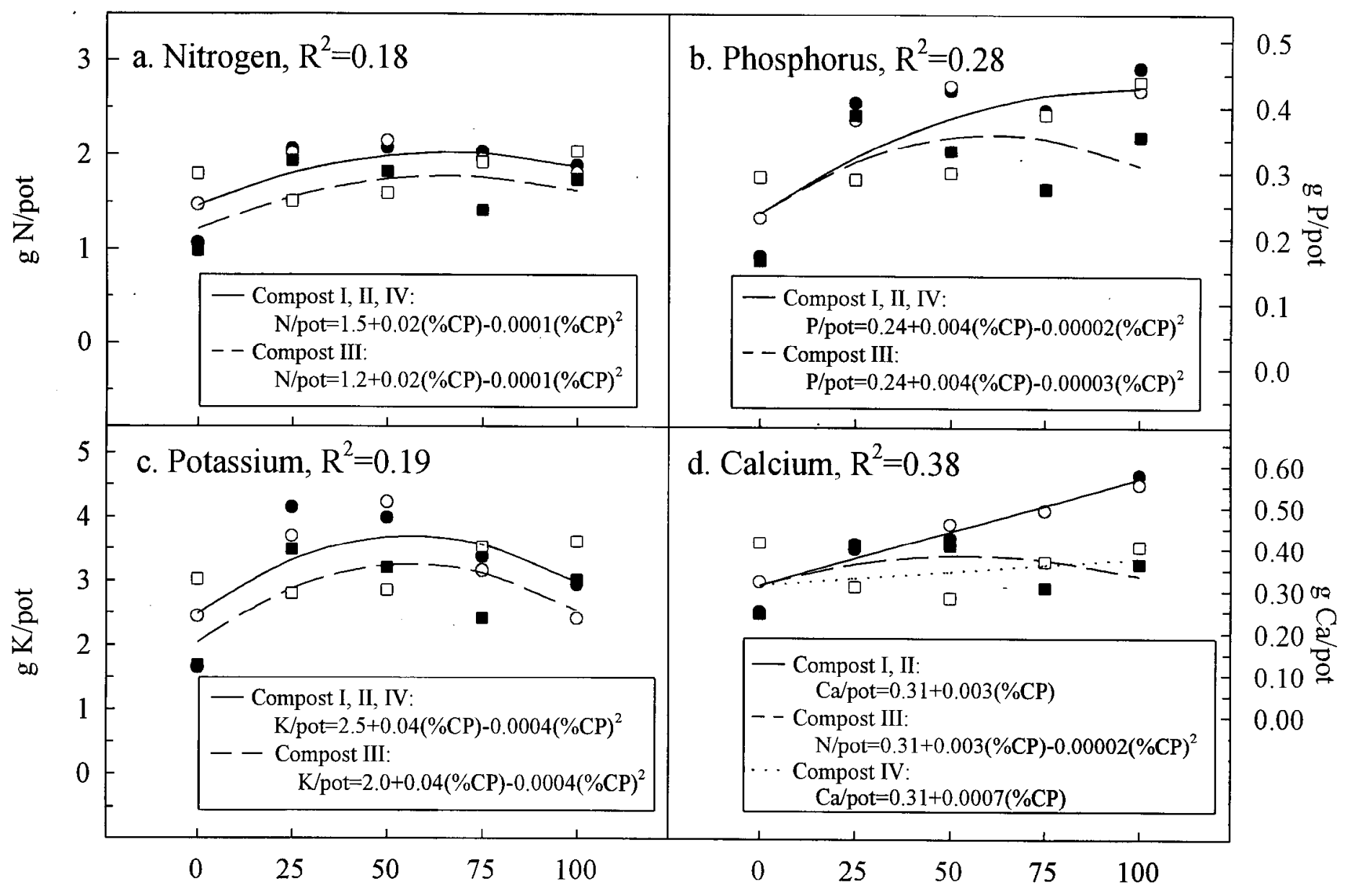

\section{Percent Compost $(\% \mathrm{CP})$}

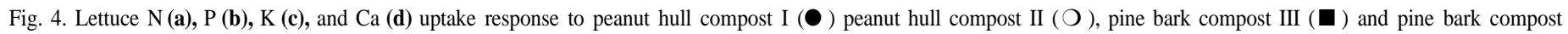

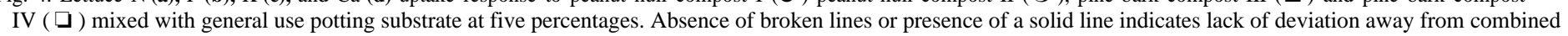
response to percentage compost.

$90 \mathrm{mg} \mathrm{Zn/kg}$ for both peanut hull composts (Fig. 2d). Zinc concentration in pine bark compost III substrate was less than pine bark compost IV substrate (Table 1), which indicated that the linear increase in $\mathrm{Zn}$ lettuce concentration with increasing percent compost may have been affected by substrate $\mathrm{pH}$ (Fig. 2d).

Iron uptake was the same for all four composts, responding quadratically to increasing percentage compost (Fig. 3a). Iron uptake increased up to $50 \%$ compost, after which it declined. Decline in uptake was due to a decrease in lettuce Fe concentration (Fig. 2b) and yield (Fig. 1). However, Fe concentration was above sufficiency ranges across compost substrates (Table 3). Manganese and $\mathrm{Zn}$ uptake increased curvilinearly with increasing percentage of compost. However, the magnitude of $\mathrm{Zn}$ uptake was greatest from pine bark compost IV (Fig. 3b), likely owing to greater concentration in the compost component. Manganese uptake was most like influenced by the previously discussed effects of $\mathrm{pH}$ (Fig. 3c). Copper uptake was greatest from pine bark compost IV, despite similar $\mathrm{Cu}$ concentration between the two pine bark composts. The difference was due to the yield differences between compost III and IV (Fig. 1). Copper uptake increased linearly from $0.5 \mathrm{mg} /$ pot with no compost to $1.16 \mathrm{mg} /$ pot at $100 \%$ pine bark compost IV and 0.76 for all other composts (Fig. $3 \mathrm{~d}$ ).

Aluminum was also an element in significant quantity within each of the composted materials (Table 1). Pine bark composts generally contained more Al than peanut hull composts. Aluminum was not added in the modified Hoagland and Arnon (1950) nutrient solution (Table 2). Uptake of Al remained constant with percentage compost, and greatest uptake was from pine bark compost IV with $4.1 \mathrm{mg} \mathrm{Al} /$ pot (data not shown). Mengel and Kirkby (1982) state that plants generally contain $200 \mathrm{mg} \mathrm{Al} / \mathrm{kg}$. Aluminum concentration in the lettuce was constant $(130 \mathrm{mg} \cdot \mathrm{kg})$ at all mixes of pine bark composts and declined with increasing percentage of peanut hull compost (data not shown). Aluminum at all levels of compost does not appear to be of physiological concern for use of these composted materials.

Lettuce $\mathrm{N}, \mathrm{P}, \mathrm{K}, \mathrm{Ca}$, and $\mathrm{Mg}$ data were collected to help assess lettuce health. All tissue concentrations of $\mathrm{N}, \mathrm{P}, \mathrm{K}$, and $\mathrm{Mg}$ were within or slightly above sufficiency ranges for Boston-type leaf lettuce (Table 3) (Jones et al., 1991). Calcium concentration was slightly below the sufficiency range, which could be easily corrected with addition of lime. Compared to other composts, pine bark compost III generally reduced uptake of $\mathrm{N}, \mathrm{P}, \mathrm{K}, \mathrm{Ca}$, and $\mathrm{Mg}$ by lettuce (Fig. 4, Mg graph not shown). Differences associated with pine bark compost III were most likely due to the $\mathrm{pH}$ effect on plant vigor and nutrient availability in the substrate. Plant N, P and $\mathrm{K}$ uptake followed a quadratic relationship for all compost sources 
(Fig. 4). Calcium and $\mathrm{Mg}$ uptake increased linearly with increasing percentage of peanut hull compost and pine bark compost IV (Fig. $4 \mathrm{~d}, \mathrm{Mg}$ data not shown). Calcium uptake from pine bark compost III, however, increased up to $50 \%$ compost, after which uptake declined. Although $\mathrm{Ca}$ and $\mathrm{Mg}$ concentrations of composted materials were similar (Table 1), there was more uptake of these two elements from peanut hull composts above the $50 \%$ compost mixture compared to pine bark composts.

\section{Conclusions}

Broiler litter composted with peanut hulls or pine bark provides a suitable potting substrate component when mixed with a commercial potting substrate such as Promix. Greatest lettuce fresh weight yields were from broiler litter composted with peanut hulls mixed with Promix at a ratio of 3 compost : 1 Promix. Nutrient uptake was also improved with use of composted broiler litter, and there was no evidence of physiologic problems stemming from nutrients or metals in the composted materials. Pine bark composted with broiler litter containing wood shavings as a bedding material appeared to require lime to increase $\mathrm{pH}$ to tolerable levels for sensitive crops such as lettuce. The need for $\mathrm{pH}$ adjustment in broiler litter and wood shavings compost : Promix mixtures was evidenced by poor yields and classical $\mathrm{pH}$ effects on nutrient concentrations in lettuce tissue.

\section{Literature Cited}

Alabama Agricultural Statistics Service. 1993. Bulletin 36. Alabama Agr. Stat., Montgomery.

Bilderback, T.E., W.C. Fonteno, and D.R. Johnson. 1982. Physical properties of media composed of peanut hulls, pine bark, and peatmoss and their effects on azalea growth. J. Amer. Soc. Hort. Sci. 107522-525.

Bosch, D.J. and K.B. Napit. 1992. Economics of transporting poultry litter to achieve more effective use of fertilizer. J. Soil Water Conservation 47:342-346.

Chaney, R.L. and P.M. Giordano. 1977. Microelements as related to plant deficiencies and toxicities, p. 235-279. In: L.F. Elliot, and F.J. Stevenson (eds.). Soils for management of organic wastes and waste waters. SSSA, ASA, CSSA, Madison, Wis.

Chaney, R.L. 1983. Plant uptake of inorganic waste constituents, p. 5076. In: J.F. Parr, P.B. Marsh and J.M. Kla (eds.). Land treatment of hazardous wastes. Noyes Data Corp., Park Ridge, N.J.

Chen, Y., Y. Inbar, and Y. Hadar. 1988. Composted agricultural wastes as potting media for ornamental plants. Soil Sci. 145:298-303.

Dowdy, R.H. and W.E. Larson. 1975. The availability of sludge-borne metals to various vegetable crops. J. Environ. Quality 4:278-282.

Flynn, R.P. and C.W. Wood. 1992. Temperature versus chemical measurement for co-composted broiler litter maturity, p. 367-372. In: Proc. Natl. Poultry Waste Mgt. Symp., Birmingham, Ala.

Freund, R.J. and R.C. Littell. 1991. SAS system for regression. 2nd ed. SAS Inst. Gary, N.C.

Golueke, G.G. 1977. Biological reclamation of solid wastes. Rodale Press, Emmeaus, Pa.

Hall, B.M. 1993. Broiler litter effects on crop production, soil properties, and water quality. MS thesis. Auburn Univ.
Hileman, L.H. 1967. The fertilizer value of broiler litter. Univ. of Arkansas, Fayetteville, Agr. Expt. Sta. Rpt. Ser. 158

Hoagland, D.R. and D.I. Amon. 1950. The water-culture method for growing plants without soil. California Agr. Expt., Univ. of California, Davis. Circ. 347

Hoitink, R.A.J. 1980. Composted bark, a lightweight growth medium with fungicidal properties. Plant Dis. 64:142-147.

Jones, Jr., J.B., B. Wolf, and H.A. Mills. 1991. Plant analysis handbook. Micro-Macro Publ., Athens, Ga.

Kingery, W.L., C.W. Wood, D.P. Delaney, J.C. Williams, G.L. Mullins, and E. van Santen. 1993. Implications of long-term land application of poultry litter on tall fescue pastures. J. Prod. Agr. 6:315-395.

Kingery, W.L., C.W. Wood, D.P. Delaney, J.C. Williams, and G.L. Mullins. 1994. Impact of long-term application of broiler litter on environmentally related soil properties. J. Environ. Quality 23: 139-147.

Lorenz, O.A. and P.N. Maynard. 1988. Knott's handbook for vegetable growers. 3rd ed. Wiley, New York.

McKenna, I.M., R.L. Chaney, and F.M. Williams. 1991. The effects of cadmium and zinc interactions on the accumulation and tissue distribution of zinc and cadmium in lettuce and spinach. Environ. Pollution 79:113-120.

Mengel, K. and E.A. Kirkby. 1982. Principles of plant nutrition, 3rd ed. Intl. Potash Inst., Bern, Switzerland.

National Research Council. 1993. Opportunities to improve soil and water quality. Soil and water quality: An agenda for agriculture. Natl. Acad. Press, Washington, D.C. p. 79.

Pokorny, F.A. 1982. Pine bark as a soil amendment. U.S. Dept. of Agr. For. Serv. Tech. Publ. R8-TP4. p. 131-139.

Raviv, M., S. Tarre, Z. Geler, and G. Shelef. 1987. Changes in some physical and chemical properties of fibrous solids from cow manure and digested cow manure during composting. Biol. Wastes 19:309-318.

Robinson, E.L., and D. Burdick. 1978. Apparent growth inhibitor in hulls of peanut. Crop Science 18:688-689.

SAS Institute. 1988. SAS/STAT user's guide. release 6.03. SAS Institute, Gary, N.C.

Stevenson, A.H., T.A. McCaskey, and G.G. Ruffin. 1990. A survey of broiler litter composition and potential value as a nutrient resource. Biol. Wastes 34: 1-9.

USDA-NASS. 1993a. Agricultural statistics 1993. U.S. Govt. Printing Office, Washington, D.C.

USDA-NASS. 1993b. Floriculture crops 1992. U.S. Govt. Printing Office, Washington, D.C.

Walker, C.D. and R.M. Welch. 1987. Low molecular weight complexes of zinc and other trace metals in lettuce leaf. J. Agr. Food Chem. 38:721727.

Wang, T. and F.A. Pokorny. 1989. Pecan shells as an organic component of container potting media. HortScience 24:75-78.

Wilkinson, S.R., J.A. Stuedemann, D.J. Williams, J.B. Jones, Jr., R.N. Dawson, and W. A. Jackson. 197 1. Recycling broiler litter on tall fescue pasture at disposal rates and evidence of beef cow health problems, $p$. 321-324. In: Livestock waste management and pollution abatement. Proc. Amer. Soc.. Agr. Eng. Publ. Proc. no. 271, St. Joseph, Mich.

Wood, C.W. and D.G. Westfall. 1989. Beneficial re-use of spent refinery catalyst as $\mathrm{P}$ fertilizer for dryland winter wheat. Hazardous Waste Hazardous Materials 6:241-250.

Wood, C.W. 1992. Broiler litter as a fertilizer: benefits and environmental concerns, p. 304-312. In: Proc. Natl. Poultry Waste Mgt. Symp., Birmingham, Ala. 